Studia Anglica Posnaniensia 48/4 2013

doi: 10.2478/stap-2013-0015

\title{
(BREAKING) THE LAW: SOCIAL CONTROL, SELF-HELP AND VIOLENCE IN THE TALE OF GAMELYN
}

\author{
JOANNA LUDWIKOWSKA
}

Faculty of English, Adam Mickiewicz University in Poznań

\begin{abstract}
Fourteenth century England experienced social changes which influenced the attitude to crown law and triggered a growing distrust to law and its representatives. The progressing development of the gentry complicated the defining of offences, and diversified the means of punishing them. The Tale of Gamelyn presents a conflict between two brothers, sons of a knight, which went beyond the confinements of the household, transforming itself into a conflict between law and justice. Their feud is a cross-complaint concerning land, which soon turns into a spiral of violence in which one brother uses law to control and punish, and the other uses crime and violence to achieve justice. Using Donald Black's theory of the sociological geometry of violence (2004) and of crime as social control (1983), this article will analyze the law in the tale as a tool of social control represented by Johan, and justice acquired with the use of self-help by Gamelyn. The article will attempt to prove that the story presents a complex relation between justice and law pinned across the varied spectrum of social classes, which Gamelyn changes a number of times, and will argue that the tale is an affirmation of violence as an underlying force of both law and justice, differing in presentation and realization according to social class.
\end{abstract}

Keywords: medieval, law, violence, social control, outlaw tales

When John de Dalton and his companions broke into the Beaumes Manor on 7 April 1347, before dawn, they kidnapped Margery, Lady De La Beche, killed Thomas the Clerk of Shipton and Michael Poynings, uncle to Lady Margery, frightened Roger Hunt, the domestic chaplain, to death, and carried off goods and chattels to the value of $£ 1,000$; later on, Dalton forced Margery to marry him. A warrant for his arrest was issued, but he was pardoned, eventually, for his service to the Crown. The Manor, as well as other lands Margery inherited from her father and her two husbands, fell to Dalton. This is but one example of 
the use of violence among the gentry ${ }^{1}$ in fourteenth century England - employed to acquire wealth, estate or even inheritance without resorting to legal means which would take more time, and would not guarantee success. Violence, as in the case of John de Dalton, could sometimes be pardoned, especially if the perpetrator took part in the wars of the king and so was allowed the king's favour. ${ }^{2}$ Especially for the lesser gentry, law appeared as only one of the ways of resolving a conflict, by no means the most satisfactory one. Violence was another of these tactics, focused primarily on the eventual acquisition of the desired outcome - regardless of the means (Fleming 2005: 56). Law, its enforcement and abuse, doubts about the outcome of trials and justice, as well as a growing disbelief in the honesty of law officials constitute the topic of interest for a large number of late medieval texts, either as the main focus or as an element of the plot (Kaeuper 1983: 11-12). One of them is the relatively obscure Tale of Gamelyn, in which the approach to law, justice, and violence is much more complex and nuanced than in other outlaw tales ${ }^{3}$.

Written in the fourteenth century, The Tale of Gamelyn represents important aspects of material and legal dealings of medieval English minor gentry ${ }^{4}$, aspects illustrated by the a feud between Gamelyn and his eldest brother, Johan. While outlining the issues connected to the question of inheritance, the text focuses on social attitudes to law, justice and violence represented by both the gentry, and members of other classes, such as servants, craftsmen, fighters, and church and law officials. The question which emerges from the reading of the story is concerned with the often elusive boundaries between law, justice and crime. All are connected by the use of violence, and involved both crime and justice, either in the form of felony or punishment. The notions of crime and justice, as well as law and outlawry are presented as relative in social terms, inviting a sociological reading of the story. According to Donald Black (1983: 34), violence may be seen as moralistic if it involves the pursuit of justice. It can be used both as a form of social control (when law responds to crime, or more generally to conduct understood as deviant), and self-help (i.e. when law does not provide compensation or gratification of a perceived abuse). Black developed this concept of violence as a double-edged sword into a theory of the "geometry of violence", a distribution of violence on a social scale according to the position of the parties involved. It takes into consideration social distances

1 Even though the exact composition of the gentry is difficult to determine as what is now collectively addressed as 'gentry' in the fourteenth century was a vague classification of landowners, knights, esquires and law officials (Gorski 2003: 65-102).

2 Malcolm Mercer identifies participation in royal wars as one of the formative elements for the rise of the gentry in late medieval England (Mercer 2010: 35).

For example, the Robin Hood tales.

Provincial landlords with predominantly local interests (Kaeuper 1983: 53). 
(class difference) between parties, their potential elevation or demotion during the conflict, as well as the direction it faces (the offender-victim relation being either in a higher-lower or lower-higher relation on the scale). It specifies the forms of violence attributed to particular conflict structures according to these criteria. The larger the distance between the parties, the more violence the conflict involves (Black 2004: 147). This article will analyze the use of violence in The Tale of Gamelyn with the use of theories of the geometry of violence, and of crime as a tool of social control (Sir Johan) and self-help (Gamelyn). The article attempts to demonstrate that the complex relation between justice and law pinned across a varied spectrum of social classes which the story presents intensifies as Gamelyn shifts between classes. Most importantly, the article argues that this medieval tale illustrates a fourteenth century affirmation of violence as an underlying force of both law and justice, differing in outlays and realization according to social classes of the parties involved. It is neither an outlaw tale of the Robin Hood type, with a noble hero, nor a propaganda story popularizing the fourteenth century legal system, but rather a more matter-offact commentary on the use of both law, and violence in crime and punishment, and the relativity of the meaning of justice.

The tale starts when Sir Johan, on his deathbed, calls for his three sons. As his last will, he wishes to divide his lands between them. According to the law of primogeniture, all heritable lands owned by Sir Johan should become the possession of his eldest son, Johan. There was also a possibility to divide them equally between Johan, and the middle son, Ote, as long as the income for each of them would suffice them to remain knights. Either way, the youngest, Gamelyn, was unlikely to inherit anything:

[a]nd wenten into counselle his londes for to dele; For to delen hem alle to on that
was her thought. And for Gamelyn was yongest he shuld have nought. All the
londe that ther was thei dalten it in two, And lete Gamelyne the yonge without
londe goo.

(The Tale of Gamelyn, 11. 44-48) ${ }^{5}$

Even though the counsel Sir Johan took from his neighbours favoured the eldest Johan (and consequently - the most traditional primogeniture rule in accordance with common law), the father chooses to give only five ploughs to Johan and Ote, and the remaining fifteen to Gamelyn, under Johan's guardianship until Gamelyn reaches adulthood:

All quotations for the Tale of Gamelyn come from the online TEAMS edition, originally by Stephen Knight and Thomas H. Ohlgren (eds), originally published in Robin Hood and Other Outlaw Tales. Kalamazoo, Michigan: Medieval Institute Publications, 1997. 
[a]nd I wil delen my londe after myn owne wille. John, myne eldest sone shal have plowes fyve, That was my faders heritage whan he was alyve; And my myddelest sone fyve plowes of londe, That I halpe forto gete with my right honde; And al myn other purchace of londes and ledes. That I biquethe Gamelyne and alle my good stedes.

(The Tale of Gamelyn, 11. 59-65)

Johan is outraged. He rightfully feels cheated out of his inheritance. Sir Johan's decision of giving both his son Johan, and Gamelyn, rights to the land posed a legal problem: the rules of inheritance are here opposed with the decision of the father in a verbal testament, both of which were considered law and were to be obeyed (Menuge 2001: 49). Johan does not conform to his father's wish, and instead uses the guardianship endowed to him over Gamelyn's share of the inheritance to take it over completely - he does not, however, claim it as his own, but rather exploits it to the limits before Gamelyn reaches adulthood.

Such a line of defence against the perceived injustice of Sir Johan's will can be seen as property confiscation, which is one of the normative ways of eliciting social control (Black 1983: 35). It seems that Johan, on good terms with the local law officials, has managed to convince them he was cheated out of lands which were rightly his, and so has been given license to take compensation in any form he thought satisfactory. Social control, after all, is a process of responding to transgressions, with the assistance of third parties (Black 1983: 36), the ability of social groups to impose norms and rules (Jensen 1951:2). And as Barbara Hanawalt and David Wallace (1999: ix) note, the standards for social control in the Middle Ages were "experimental and subject to change as were the very definitions of criminal behaviour". Johan's actions are therefore by no means illegal, and probably not that uncommon.

This, however, does not mean Johan is not the villain. The tale suggests it was Gamelyn who was abused as Johan stole his inheritance, which states a preference for the testament, local law of the father over the common law primogeniture system. It also hints, already at the beginning, that law and justice in the tale are perceived as two separate concepts: common law seems to be on Johan's side, whereas moral law (and local law) on Gamelyn's. This seems to serve as a justification of the youngest brother's actions later (van Iersel 2007: 120). The presentation of Gamelyn's brother is biased and negative, however, in fact it only allows for Gamelyn's actions to be seen as righteous by contrast undeniably, he does commit crimes a multitude of times, and nowhere is he presented as a noble and charitable hero, or defenceless victim. Johan embodies the firm rules of law often stretched and abused by the gentry (Fleming 2005: 54), and Gamelyn what might be called personal justice. Their feud forms a battleground for the two concepts as, according to Black, conflict management 
by law in social control involves feuding, confiscation and destruction of property, as well as other forms of deprivation or humiliation, whereas personal justice involves self-help in all available variations.

Since Johan belongs to the class of knights and Gamelyn does not, this conflict is not exclusively a private in-family rift about inheritance. It has a more social dimension: in the course of the story both brothers associate themselves with different and essentially mutually exclusive groups which are distant on the lines drawn by the geometry of violence. The Tale, then, shows that directions on the social axes of a conflict define the relation between law and self-help, as both are distributed unevenly across this space (Black 1983: 38) and align themselves partially with classes represented by both brothers. Johan occupies a high position on the social scale - he has law at the ready both in terms of his right to inherit, and legal authority first in the form of his allies, and then his own power as he becomes sheriff. Gamelyn begins almost as Johan's equal, lower only in terms of land inheritance as a warden, though his status is unclear - Johan is a knight, but Gamelyn is not, which suggests that it was land ownership (from a certain amount of land owned) that elevated its owner to the position of a knight. For Gamelyn this means that hard as he might try, he will never rise socially as long as Johan owns the plots of land bequeathed to Gamelyn. His actions prove this, as he acts as if law is unavailable to him, and behaves as one with a grievance to a social superior. As Hanawalt claims, resorting to justice other than personally administered could have proven too remote and unreliable for those who were in need of immediate assistance (Hanawalt and Wallace 1999: ix), suggesting the law was neither equally available nor helpful for members of all classes.

Gamelyn personifies those to whom justice was unavailable due to their low social position, and so exemplifies an approach to law as only one path to achieve justice, as well as the distrust law and its institutions were treated with in the fourteenth century. Gamelyn class-wise is therefore neither a knight, nor a landowner, he is also not a servant. His elusive status can be described by T.A. Shippey's (2000: 79) definition of a 'yeoman', partially explaining his roughness and violence in the Tale. In terms of social classes, yeomanry underwent an addition of meaning from the late fourteenth century definition as simply the "upper stratum of freeborn commoners" (Singman 1998: 35) or more specifically soldiers lower in rank than esquires or knights, to potentially riotous vagabonds (Rollison 2010: 457), and in Shippey's interpretation of the Tale, Gamelyn is attributed with the negative traits of yeomanry. In the light of Black's theory, on the other hand, this allows him to migrate on the social scale as the tale unravels, illustrating the use of violence in many possible combinations of social relations. Until the end of the story, he moves downwards on the social scale - he falls three times: when he commits murder, aligns himself with a servant to attack church officials, and finally when he becomes a bandit. 
Both the character of Gamelyn, and Johan, represent not only their classes, but also the use of law, justice, and violence among these classes. Johan is a particularly interesting character, as he seems to stand for all that was most hated in the legal apparatus: officials bending the law for their own advantage, or abusing it openly for their own means. What causes friction in this line of thinking about Johan is his firm and obvious right for the land of his father, according to common law and custom. Both were of large importance in the fourteenth century, which only towards its end observed a move towards the unification of law under the Crown. Most of the time, local matters were resolved locally, and the king was appealed to only in extreme and exceptional cases. Judges, therefore, had considerable leverage for giving their verdicts as long as they did not oppose either crown or canon law. In the tale law itself, however, does not cater for the needs of those subject to it, as the case of Gamelyn proves. Justice, or moral law, seems to stand outside any prescribed forms of law, and therefore the fact that it stands on Johan's side is irrelevant - after a closer reading, the matter of inheritance appears to be secondary for the plot, and the foreground becomes the way the conflict is resolved.

In the context of Ricardian law in England the ensuing conflict between the brothers can also be viewed from the perspective of folk law, defined by Richard Green (2002: 81) as characterized by a drive for reconciliation, a strong sense of community, the importance of judicial oaths and the favouring of earlier modes of solving conflicts such as duels. The Tale of Gamelyn is an instance of the complicated relationship between elements of this folk law and the inequities of common law. In Green's discussion of The Tale of Gamelyn, violence emerges from the fourteenth century crisis of, and resistance to, central authority (Green 2002: 164) which was particularly pronounced in social reactions to the attempts of centralizing law and legal institutions. Violence in The Tale of Gamelyn according to Green is directly provoked by Johan breaking his word given to Gamelyn a number of times, seen as the breaking of the judicial oath (Green 2002: 194-197). This reading partially explains why outlawry was seen as appropriate for Gamelyn to solve his feud with Johan, yet the conflict between folk law and crown law as central to The Tale of Gamelyn can be investigated more deeply by a closer scrutiny of the mechanisms of social control and self-help.

Johan represents the transgressions done in accordance with the law in the spirit of social control: he exploits Gamelyn's lands and goods, and then plots against Gamelyn, even more so when he becomes a sheriff. Johan stands for all those who know, and are able to use, the law to their own advantage. Gamelyn on the other hand embodies those who were somehow cheated and abused by means of law, who decide to take justice into their own hands. His self-help is a series of actions intended as punishment for those who abuse the law (hence not 
only Johan, but also judges and clerics in the jury receive this punishment). It is an expression of disapproval and a strive to achieve compensation for a harm done, since self-help always involves a series of offences (Black 1983: 34), and Gamelyn's actions are, indeed, crimes. His use of violence in the text is neither justified nor frowned upon. Such clearly avoided judgement of Gamelyn's actions is a comment on violence as being the last resort for all those mistreated by law officials. It also suggests that violence was seen as the simplest and most effective way of achieving immediate justice or revenge, as opposed to adjourning legal proceedings, especially when the opposing parties stood in a considerable distance on the geometrical scale. In The Tale of Gamelyn this strategy proves successful, particularly in the light of the class alignments both brothers fall into.

After their father's death, Johan takes control of Gamelyn's lands as his guardian, although he does not take them over as owner. As mentioned earlier, his duty is not just to benefit from the land, possessions and game, but to keep them ready for his charge to take when he reaches adulthood (Menuge 2001: 50, 54), and this is what seems to constitute the problem: he not so much stole Gamelyn's inheritance, as he abused it and brought to ruin - he did not break the law, but stretched it. Only when Gamelyn grows older does he realize that his lands are being exploited, but unkempt:

Sone the elder brother giled the yonge knave; He toke into his honde his londe and his lede, And Gamelyne him selven to clothe and to fede. He clothed him and fedde him evell and eke wroth, And lete his londes forfare and his houses bothe, His parkes and his wodes and did no thing welle; And sithen he it abought on his owne felle.

(The Tale of Gamelyn, 11. 74-80)

Johan quickly degrades Gamelyn from a landowner to a subject, fed and sheltered for the cost of all his ploughs of land. Hence what Johan really takes away from Gamelyn is the knightly title, joint to the land, which Gamelyn cannot win back otherwise than by reclaiming his inheritance.

What follows is a power struggle between the brothers, in which they interchangeably triumph over each other. When Gamelyn attempts at negotiating with Johan, he is attacked, overpowers his assailants, and discovers that his strength might become useful in the conflict with his brother. He defends himself against his brother's attacks so effectively that, eventually, there is no one who wants to stand against him:

Whan Gamelyne segh hem comen he loked overall, And was ware of a pestel stode under the wall; Gamelyn was light and thider gan he lepe, And droof alle his brotheres men right sone on an hepe. And loked as a 
wilde lyon and leide on good wone; And whan his brother segh that he byganne to gon; He fley up into a loft and shette the door fast; Thus Gamelyn with his pestel made hem al agast.

(The Tale of Gamelyn, 11. 127-133)

The overpowered Johan promises to give Gamelyn all his lands back. Gamelyn, convinced of his victory, ventures on a small quest outside the castle. Here, the story contains a subtle reference to knightly romances - had it been a romance, Gamelyn would have proved his knighthood by fighting the champion he met on this journey. At this point he can potentially become a classic hero of a romance, as is already endowed with the income required to be a knight (Gorski 2003: 6567), yet his fight with a champion does not grant him the title. The importance of this event is twofold. On the one hand, it is a sign his ownership of the land is not confirmed and that the struggle between the brothers will continue. On the other hand, it is an interesting meta-comment on the genre of the tale - the conscious choice of not following the romance structure, and an allusion to its main concern - an illustration of social reality. Had he been knighted, it would have provided a twist to the story changing the power balance to Gamelyn's advantage. Yet the aim was clearly not to create a chivalric hero of the same type as for instance Sir Isumbras, but to comment on the justification of the use of violence. His journey is therefore not a knightly quest of self-discovery. It is a rite of passage, but only for him to realize the power of his own physical strength. He is, therefore, not a typical hero ennobled by his sufferings, but rather a more realistic, ambiguous character concerned with his personal interest, slightly a brute at heart. ${ }^{6}$

When he returns to the castle, the doors are barred against him. Infuriated, he breaks inside, kills the porter and manages to take the whole castle by force. Satisfied, he feasts along with a group of his followers at the expense of his brother, who flees into one of the towers, afraid for his life. When Gamelyn's guests depart, Johan manages to win back Gamelyn's trust, and again it appears the conflict has ended. But, as soon as opportunity arises, Johan has Gamelyn bound, this time with reasons much better than his personal grievance - Gamelyn is to be tried for the murder of the castle's porter. According to both common and canon law, Gamelyn committed a crime (and a sin) and thus by all standards should be punished:

Gamelyn overtoke the porter and his tene wrake, And girt him in the nek that the boon to-brake, And toke hym by that oon arme and threwe hym in a welle, Seven fadme it was depe as I have herde telle.

(The Tale of Gamelyn, 11. 323-327)

6 For a discussion of Gamelyn's status as a hero as defined by his social status, see Nancy Mason Bradbury's "Gamelyn” in Neil Cartlige's Heroes and Anti-heroes in Medieval Romance (2012), pp. 129-146. 
By committing murder and denying the deed its legal consequences, Gamelyn falls down on the social scale, becoming a criminal. The way he is presented, however, awakens sympathy rather than condemnation. He has a righteous reason for revenge and this justifies his actions, even though he killed a man. Thus he denies the power of law over those who feel they have been abused by it. From a dependant of his brother deprived of the knightly title, he turns into a criminal. This increase in the distance on the geometry scale becomes an invitation to a far more violent conflict.

Further in the Tale, Gamelyn is lawfully punished for his crime (Scattergood 1994: 166) - publicly bound to a pole, and denied food and drink for two days - a relatively light punishment, as had he been a servant or peasant, the punishment would have been much more severe (Hanawalt 1998: 54). For him, it was restricted only to the family household, and bound by the code normally assigned to the trials of members of the gentry, with additional lenience on the side of Johan due to their kinship. From Johan's point of view the direction of the conflict is downwards on the scale, and he treats Gamelyn with a somewhat familial lenience. This can be read as a degree of understanding of the law towards some variants of self-help (Black 1983: 40), as well as proof that there is less violence when the conflict is directed from a higher to a lower position on the geometry scale. From Gamelyn's point of view, the direction of the conflict is upwards, and the distance between him and Johan subjectively much further, hence the level of violence his actions present. He is driven by hatred towards his brother, and not only refuses to accept the justifiability of his punishment, but also never considers any kind of retribution. Bound in his brother's prison, Gamelyn plots how to humiliate Johan, and plans an escape.

He allies himself with a servant - Adam Spenser, promising him a part of his lands if he manages to regain them:

Therfore brother Adam lose me out of bondes, And I wil parte with the of my free londes." "Up such forward," seide Adam, "ywis, I wil do therto al that in me is." "Adam," seide Gamelyn "as mote I the, I wil holde the covenaunt and thou wil me."

(The Tale of Gamelyn, 11. 435-440)

By taking Adam's advice a number of times Gamelyn recognizes him if not as superior than at least an equal, trusting the servant's judgement over his own instinct. Following Adam's suggestion, he first tries to present his case to the church officials at his brother's castle, but finds no sympathy. Observing that they stand steadfast in one line with the law (and Johan): 
[t]han seide an abbot, sorowe on his cheke, "He shal have Cristes curs and Seinte Maries eke, That the out of prison beggeth or borowe, And ever worth him wel that doth the moche sorowe." After that abbot than speke another, "I wold thine hede were of though thou were my brother! Alle that the borowe foule mot hem falle!" Thus thei seiden alle that were in the halle. Than seide a priour, evel mote he threve! "It is grete sorwe and care boy that thou art alyve." "Ow!" seide Gamelyn, "so brouke I my bone! Now have I spied that frendes have I none Cursed mote he worth both flesshe and blood, That ever doth priour or abbot eny good!"

(The Tale of Gamelyn, 11. 508-522)

On the one hand, the appeal to the church officials appears justified: after all, he does feel wronged by his brother. On the other hand, it has been proven a few times already that the law will not help him, and his behaviour throughout the story has been consistent with this assumption. Since it is an appeal to the clergy, not lay men of law, it might also illustrate the fourteenth century increase in anti-clericalism, and a negative comment on how corrupt and materialistic the clergy has become. However, it is beyond doubt, even with the allowance for the medieval relativity of the notion of crime, that he did commit an unlawful act. Two comments emerge from this point in the story: that the law is to a large extent a construct which not necessarily serves the rights of all people equally, but is a very convenient tool of abuse, and that violence is not a crime if it serves justice - even, if it simultaneously stands in opposition to law. Also, Gamelyn's absolute trust towards Adam, underlying Gamelyn's status as a very untypical hero, at the same time makes him a character relatively easily identifiable to a wider, non-aristocratic audience. Violence that Gamelyn uses with the help of Adam makes him fall lower on the social scale. He attacks and hurts everybody in the room, adding misconduct and blasphemy to murder:

Whan he come to Adam he took that on staf, And bygan to worch and good strokes yaf. Gamelyn come into the halle and the spencer bothe, And loked hem aboute as thei hadden be wrothe; Gamelyn spreyeth holy watere with an oken spire, That some that stode upright felle in the fire. Ther was no lewe man that in the halle stode, That wolde do Gamelyn enything but goode, But stoden bisides and lete hem both wirche, For thei had no rewthe of men of holy chirche; Abbot or priour, monk or chanoun, That Gamelyn overtoke anoon they yeden doun Ther was noon of alle that with his staf mette, That he ne made hem overthrowe to quyte hem his dette.

(The Tale of Gamelyn, 11. 529-543)

When the sheriff comes for Gamelyn as he "had ydo a sorye rees, Boundon and wounded men ayeinst the kingges pees" (The Tale of Gamelyn, 11. 575-576), he flees to a nearby forest. From a squire punished for murder and brutality, he becomes an outlaw. 
Upon entering the forest they meet a group of men, to whom Gamelyn presents his prowess and strength:

"Thoo ye fette to you fyve than be ye twelve!" Whan they harde by his word that myght was in his arme, Ther was noon of hem that wolde do hym harme.

(The Tale of Gamelyn, 11. 586-589)

And when he is introduced to the king of outlaws, he instantly makes Gamelyn his deputy:

Tho was the maistere outlaw into counseile nome, And tolde howe it was Gamelyn that thider was come. Anon as he herd how it was byfalle, He made him maister under hym over hem alle.

(The Tale of Gamelyn, 11. 720-723)

The degree to which Gamelyn has been maltreated guarantees recognition among the men of the forest, especially that there is a potential possibility of later benefits should Gamelyn win back his lands. Maurice Keen (1961: 93) claims that the organization of the outlaws is not convincing, and in fact resembles a class hierarchy typical for all groups in medieval England. However, Gamelyn here is not a representative of his class anymore, as not only was he degraded by his brother, but also by his own actions became a criminal and bandit. He enters the forest not as a noble outlaw, but a criminal whose class is difficult to determine at best, and is simply low at worst. The rapid initial success he experiences among the bandits is not thanks to his position in hierarchy, but - yet again - because of his exceptional physical strength.

The whole group operates on the simple conviction that it should be the strongest who rules. He proves that he remains outside the class of knights, to which both his brothers belong (referred to as Sir Johan, Sir Ote, as was their father), and also that he does not think along the same lines as members of this class would. Banditry is, after all, a form of rebellion by those at the bottom of society against their social superiors (Black 1983: 38), and this is precisely who Gamelyn becomes - a bandit. His outlawry is distinct from that of Robin Hood, because he is not noble and selfless, and he does not use violence towards one class, or group, to benefit another. He is simply a violent man fighting to avenge his own hurts. Violence became the simplest and most effective solution every time he was in need. After he appealed to clergymen, and was turned down, he never again sought help among law officials, but always resorted to physical violence. Therefore indeed, the outlaws retain a hierarchy, however it is not based on class categorization, but on the unifying negative attitude to the law, 
and positive to violence. The one who has the most to fight against, and does it most violently, becomes the leader. This is then a sociological rule, independent of the medieval class division. Gamelyn simply fought his way into a classindependent hierarchy, because he consciously left his own class behind.

The final, and most surprising, stage in Gamelyn's shifting between social classes is his restoration to the gentry, which takes place after his ultimate act of violence. Finally, brought in front of the jury again, he is liable to immediate execution for the refusal of participating in two previous trials in absentia, for murder, brutality and banditry. Punishment was hanging - at this point in the story Gamelyn is treated as a common criminal (Hanawalt 1998: 55). However, his brother, Sir Ote, vouches for him and bails him out. Ote is a balancing force, who wants to avoid conflict even though he does not support Gamelyn's actions. Sir Johan, a sheriff, agrees to this solution, but only on the condition that if Gamelyn fails to arrive, Sir Ote will be put on trial and executed instead. By doing this Sir Johan maintains his high position as a law official, and even though he is presented as negatively as possible, his actions seem only natural in the context to legitimate social control ${ }^{7}$. Gamelyn, on the other hand, deteriorates class-wise, to gain power of a much simpler nature, but also much more effective than legal meanderings. The text then acknowledges violence in both its physical aspect of selfhelp, and its social aspect as a means of social control as at no point in the tale the use of violence as punishment is contested. It is the injustice Johan treats Gamelyn with which is the heart of the matter. The climax of the Tale undoubtedly points to the superiority of the use of force. It seems that the text promotes physical violence as it is the only possibility Gamelyn has to win over his brother. Because the law seems to work against justice, violence is used against it.

On bail, Gamelyn gathers the other outlaws and leads them back to the courtroom. He attacks the officials, then hangs his brother, the judge, and the jury. His actions constitute the ultimate defeat of the legal system represented by his brother:

The justice satte stille and roos not anon; And Gamelyn cleved his chekebon; Gamelyn toke him in his armes and no more spake, But threwe hym over the barre and his arme brake ... He ordeyned hym a quest of his men stronge; The justice and the shirreve both honged hie, To weyven with the ropes and the winde drye; And the twelve sisours (sorwe have that rekke!) Alle thei were honged fast by the nekke.

(The Tale of Gamelyn, 11. 891-924)

7 The one with the complaint in the face of law is the offender: the state prosecutes the case in its own flow, and often the original offender against morality acts as witness against the man he victimized, in cross-complaints the one who takes up self-help is the offender, criminal (Black 1983: 38). 
At this point, the escalation of violence is no longer viewed as a crime - the law is defeated in the courtroom, and what triumphs is what seems to be its opposite - justice. Having taken the whole court by force, Gamelyn is congratulated by Sir Ote, and later pardoned by the King, who makes Gamelyn the Chief Justice of the forest:

[t]hei maden pees with the king of the best sise. The king loved wel Sir Ote and made hym justise. And after, the king made Gamelyn in est and in west, The cheef justice of his free forest;

(The Tale of Gamelyn, 11. 928-931)

Such an elevation might be surprising from the legal point of view, but it remains coherent with the logic of the Tale. After Gamelyn's ultimate downfall on the social ladder, violence reaches its ultimate level as the distance between him and his brother has reached its limit on the violence geometry scale. Gamelyn's successful though violent self-help is gratified by his restoration, and then elevation to a high position on the social ladder, proving that successful self-help, paradoxically, turns into a solid background for becoming a law official.

The Tale of Gamelyn is a text which presents the audience with a character easily acceptable for both the low gentry, squires, as well as servants and people of lower social ranks, all allied under the banner of mistrust to the legal system. Gamelyn is a character who shortly participates in the lives of all these groups, as he changes his social class a number of times, and presents the increasing degree of the use of violence as proportional to the growing distance on the violence geometry scale. Gamelyn proves that violence is the best and simplest solution to inequalities and injustice, and that it might serve as a means of defending oneself, and achieving one's aims without fear of consequences. The king's pardon and Gamelyn's elevation to Chief Justice prove that in the Tale, violence is much more powerful than the law, and also that the justice, out of all four concepts touched upon by the tale (law, justice, crime, violence), is the most relative of all, whereas the law is the least respected. Gamelyn's rights to land were more moral, than legal, and all his actions to reclaim it were illegal. This moral law gave rise to a search for justice, and for the use of law as social control to ensue injustice. Eventually, even though he has acted selfishly and violently, he is awarded a position of a law official himself. He was not a hero, so there is no narrative promise in the tale that he will prove to be a better judge or sheriff than Johan, suggesting that a legal office has little to do with promoting justice. Therefore the Tale tells a story of a power struggle both fought and won with the use of violence, eventually suggesting no moral victories and losses, but being simply a comment on legal and social reality and their relation to violence - the stronger one wins. There is no need to obey the law, as violence 
is much more reliable. It is gratified and affirmed the moment Gamelyn is awarded the Chief Justice position. The variation of the type of violence differs according to the social class, ranging from less to more physical according to the geometry scale, proving it is never gone regardless of the social relations between parties involved - it is simply dependant on their social distance. Violence is a common, yet double-edged sword - used as a means of punishment both within and outside the legal system, and an integral element of justice, however it is to be understood.

\section{REFERENCES}

Black, Donald. 1983. Crime as social control. American Sociological Review 48(1). 34-45.

Black, Donald. 2004. Violent structures. In Margaret A. Zahn, Henry H. Brownstein, and Shelly L. Jackson (eds.), Violence: From theory to research, 145-158. New York: Matthew Bender.

Bradbury, Nancy Mason. 2012. Gamelyn. In Neil Cartlige (ed.), Heroes and anti-heroes in medieval romance. 129-144. Cambridge: D.S. Brewer.

Cartlige, Neil (ed.). 2012. Heroes and anti-heroes in medieval romance. Cambridge: D.S. Brewer.

Field, Rosalind. 1999. Tradition and transformation in medieval romance. Cambridge: D.S. Brewer.

Fleming, Peter. 2005. Politics. In Raluca Radulescu and Alison Truelove (eds.), Gentry culture in late medieval England, 50-62. Manchester: Manchester University Press.

Green, Richard Firth. 2002 [1999]. A crisis of truth. Literature and law in Richardian England. Philadelphia: University of Pennsylvania Press.

Gorski, Richard. 2003. The fourteenth century sheriff: English local administration in the Late Middle Ages. Woodbridge: The Boydell Press.

Hanawalt, Barbara. 1998. Of good and ill repute: Gender and social control in medieval England. New York: Oxford University Press.

Hanawalt, Barbara and David Wallace (eds.). 1999. Medieval crime and social control. Minneapolis: University of Minnesota Press.

Hanawalt, Barbara and David Wallace. 1999. Introduction. In Barbara Hanawalt and David Wallace (eds.), Medieval crime and social control, ix-xvi. Minneapolis: University of Minnesota Press.

Iersel, Geert van. 2007. The twenty ploughs of Sir John: The tale of Gamelyn and the implications of Acreage. In Thea Summerfield and Keith Busby (eds.), 111-122. People and texts: Relationships in medieval literature. Amsterdam: Rodopi.

Jensen, Gary F. 2003. Social control theories. In Richard A. Wright and J. Mitchell Miller (eds.), Encyclopedia of criminology. New York: Routledge. http://sitemason.vanderbilt.edu/files/1/13Bguk/soccon.pdf (date of access 10 Oct 2012). 
Keen, Maurice Hugh. 1987. The outlaws of medieval legend. London: Routledge.

Knight, Stephen and Thomas H. Ohlgren (eds.). 1997. The tale of Gamelyn: Introduction. Originally published in: Robin Hood and other outlaw tales. Kalamazoo, Michigan: Medieval Institute Publications. TEAMS edition: http://www.lib.rochester.edu/ camelot/gamint.htm.

Meale, Carol M. (ed.). 1994. Readings in medieval English romance. Cambridge: D.S. Brewer.

Menuge, Noel James. 2001. Medieval English wardship in romance and law. Cambridge: D.S. Brewer.

Putter, Ad and Jane Gilbert (eds.). 2000. The spirit of English medieval popular romance. Harlow: Longman.

Mercer, Malcolm. 2010. The Medieval gentry: Power, leadership and choice during the Wars of the Roses. London: Continuum.

Radulescu, Raluca and Alison Truelove (eds.). 2005. Gentry culture in Late Medieval England. Manchester: Manchester University Press.

Rollison, David. 2010. A Commonwealth of the people: Popular politics and England's Long Social Revolution 1066-1649. New York: Cambridge University Press.

Scattergood, John. 1994. The tale of Gamelyn: The noble robber as provincial hero. In Carol M. Meale (ed.), Readings in medieval English romance, 159-194. Cambridge: D.S. Brewer.

Shippey, T.A. 2000. The tale of Gamelyn: Class warfare and the embarrassments of genre. In Ad Putter and Jane Gilbert (eds.), The spirit of English medieval popular romance, 7896. Harlow: Longman.

Singman, Jeffrey L. 1998. Robin Hood: The shaping of a legend. Westport: Greenwood Press.

Summerfield, Thea and Keith Busby (eds.). 2007. People and texts: relationships in medieval literature. Amsterdam: Rodopi.

Wright, Richard A. and J. Mitchell Miller (eds.). 2003. Encyclopedia of criminology. New York: Routledge.

Zahn, Margaret A., Henry H. Brownstein and Shelly L. Jackson (eds.). 2004. Violence: From theory to research. Amsterdam: Elsevier. 